\title{
New Diplomacy and decolonial heritage practices'
}

\author{
Cristina E. Clopot, Casper Andersen and John Oldfield
}

What are the diplomatic potential and obligations of decolonial heritage practices? This is the issue we address in this chapter, taking as our point of departure recent debates around International Cultural Relations (ICR), which emphasize calls for cultural co-operation at a global level to promote peace and encourage resilience and economic recovery (EUNIC 2020). While well-meaning, however, the clear alignment of other forms of diplomacy with the foreign policy goals of the European Union (EU) and its member states, has made ICR difficult to implement, particularly at the state level. Too often, the influential practice of 'soft power', evident in older notions of cultural diplomacy, gets in the way of meaningful cultural co-operation, leading to the persistence of colonial agendas and Eurocentric ways of thinking, including negative perceptions of the Global South and the marginalization of those disempowered by former colonial relations (ECHOES 2021).

For these reasons, we follow the so-called New Diplomacy Studies, which moves beyond traditional state-centric ideas that regard diplomacy as the preserve of the state, foreign ministries and their authorized agents (Cooper and Hocking 2000; Eban 1999; Murray et al. 2011). Rather, "plural diplomacies' involve a broad range of diplomatic stakeholders that play a role in the dialogues and negotiations among states and groups in order to find ways of living together (Cornago 2013). State-led diplomacy is, in many cases, responsive to the initiatives and agendas of non-state agents' diplomacy, which is also notable in the heritage field (Winter 2015). In our approach, we adopt Costas Constantinou's (2013) notion of mid-space diplomacy, a form of diplomacy in which a third actor aims to enhance mediation through activities that bring two (or more) sides together in a constructive relationship. According to this formulation, the mid-space diplomat

acquires legitimacy from the interstitial-from the international or intercommunal — making the most of not taking sides or by functionally distancing oneself from the sides; in other words, uses one's craft to support actions that re-engage and re-position the "sides".

(Constantinou 2013, 145) 
This position in the middle allows more flexibility by seeking 'new knowledge and insights from plural locations, across national frontiers, from within humanity's contrasting histories, value systems, and beliefs' (Constantinou 2013, 146). Thus, it is a requirement that mid-space diplomatic stakeholders 'participate meaningfully in the formation and transformation of knowledge upon which issues are presented, debated, and decided' (Constantinou 2013, 145-6).

An important element of mid-space diplomatic practice is a willingness to adopt what Luigi Di Martino (2020) labels 'active listening': that is, an ethical approach to listening, based on a genuine interest in the other's perspective and placing listening as an outcome in and of itself. Listening is the primary characteristic of two-way communication, and practices of active listening need to be developed to achieve the long-term goals of mid-space heritage diplomacy. Nigerian author Chinua Achebe (1930-2013) articulated this form of mid-space diplomacy insightfully in an interview conducted at the University of Massachusetts, Amherst, in 1988. From the standpoint of the formerly colonized, Achebe emphasized the importance of the willingness and ability to listen within the asymmetrical relationship that continues in our postcolonial world:

We have done a lot of listening ourselves. This is a situation where you have a strong person and a weak person. The weak person does all the listening. Up to a point the strong person even forgets that the weak person may have something to say, you see, he is simply there as a fixture. You simply talk at him ... So it is important that we listen, that we develop the ability to listen to the weak. Not only in Africa, but even in your own society, the strong must listen to the weak.

(Afrikan Liberation 1988)

For us, Achebe's point is pertinent because he insists on the need to redress the terms of debate and engagement. Who does the talking and who does the listening is key, as strength and weakness are part of the positionalities in diplomatic relations, not intrinsic qualities of individuals. Moreover, Achebe reminds us that the legacies of colonialism are not exclusively about Global North and Global South relations but also concern relations within societies in the North and South. All of these elements are central if diplomacy is to have a decolonial function and not simply repeat age-old patterns of exclusion and coloniality.

As has been pointed out by several scholars, diplomacy — enacted by state agents as well as non-state agents - has been part of Western repertoires of control and dominance, particularly in colonial contexts (Constantinou 2000; Opondo 2010). Decolonial scholars like Siphamandla Zondi (2016) therefore reject new diplomatic theory and argue that it reproduces coloniality and is Eurocentric in ways that inevitably lead to the exclusion of experiences, voices and archives of people outside the geopolitical West. We recognize the 
importance of this critique and share the ambition to move from a 'Western monologue to a diverse multilogue' (Zondi 2016, 20) to allow a plurality of knowledges to play a role in diplomacy. Indeed, the decolonial critique is a forceful reminder of the need to investigate the foundations of diplomatic knowledge and rival perspectives, which mid-space diplomacy insists upon. In the context of decolonial heritage diplomacy, the notions of indigenous knowledge and community-based knowledge are central for opening spaces beyond traditional Western diplomatic discourse.

\section{Types of knowledge: indigenous, local, community}

If the acknowledgement of a broader range of diplomatic stakeholders is one of the pillars of the New Diplomacy Studies, another is a different conception of knowledge or, rather, an appreciation of different types of knowledge. This resembles the decolonial insistence on pluriverse epistemologies, which also brings to the fore the question of knowledge: who owns it, how is it constituted, where is it located? Of late, decolonial debates have focused particular attention on indigenous knowledge, that is, the traditions and belief systems of 'native' or 'aboriginal' peoples. Researchers such as Catherine Walsh (2018) use examples such as the concept of buen vivir (or sumak kawsay in Kichwa, loosely translated as 'good life') to reflect on aspects of interculturality, as this concept has become mainstreamed at a national level in Ecuador (see also Vanhulst and Beling 2014). With indigenous knowledge transferring from the margins to institutionalized and nationalized discourses, the question of what being Indigenous means and its corollary, what indigenous knowledge might consist of, becomes even more pressing.

Answering these questions is far from easy or straightforward. Definitions can also be hazy and even unhelpful. Significantly, the UN does not provide a conclusive and definitive definition of what Indigenous people might mean as a concept. Having said that, the common interpretation of indigeneity in international treaties and legislative frameworks does point to some common characteristics, among them self-identification or the continued inhabitation of lands from pre-colonized times. Often, claims to indigeneity are connected with political aims, but that is not necessarily what we are interested in here. Rather, our purpose is to consider the 'characteristics' of Indigenous people, such as their 'unique traditions', or the fact that they 'retain social, cultural, economic and political characteristics that are distinct from those of the dominant societies in which they live' (UN n.d.). Marginality and distinction thus become hallmarks of both internal and external recognition.

Article 31.1 of the UN Declaration on the Rights of Indigenous Peoples, for instance, addresses the question of indigenous knowledge in these terms:

Indigenous peoples have the right to maintain, control, protect and develop their cultural heritage, traditional knowledge and traditional 
cultural expressions, as well as the manifestations of their sciences, technologies and cultures, including human and genetic resources, seeds, medicines, knowledge of the properties of fauna and flora, oral traditions, literatures, designs, sports and traditional games and visual and performing arts. They also have the right to maintain, control, protect and develop their intellectual property over such cultural heritage, traditional knowledge, and traditional cultural expressions.

(UN 2007, 22)

Perhaps most prominent at the international level is indigenous knowledge related to the environment, often linked to the sustainable development discourse, as in the case of the buen vivir concept above (Vanhulst and Beling 2014).

Where the possibility for confusion creeps in is in the use of similar or equivalent terms that are often used interchangeably (see Oguamanam 2008; Quiroz 2002). The UN and UNESCO - to offer an example-lump together 'indigenous' and 'local' knowledge, at the same time adding a shorthand definition, namely 'the understandings, skills and philosophies developed by societies with long histories of interaction with their natural surroundings' (UNESCO n.d.). They also emphasize the intangible aspects of 'local and indigenous knowledge', such as 'social interactions, ritual and spirituality' and link this to the sustainability agenda. This sounds very much like indigenous knowledge (strictly defined) but arguably opens the way for broader and more expansive uses of the term, based on definitions of what is (and is not) considered 'local'. Anthropologists have long been writing on knowledge generated by living in particular settings, guided by situated interpretations of one's locality (Canagarajah 2002; Geertz 1983). Chidi Oguamanam ( 2008) highlights a further terminological quandary with the term 'traditional knowledge', and notes that WIPO (World Intellectual Property Organization) includes indigenous knowledge under the category of traditional knowledge, as a form of knowledge specific to Indigenous peoples.

The key point, however, is that most authors, albeit invested in the use of one term or another, highlight the marginalization of such forms of knowledge due to colonial power relations and Western-centric approaches to knowledge production, evident in the use of terms such as 'oppression' and 'destruction'. Debates about indigenous knowledge, often based on relationality rather than binaries common in many Western approaches, highlight tensions at both epistemological and ontological levels, where this 'CartesianNewtonian science is grounded upon violent epistemology that seeks to possess the earth like a master owns a slave' (Semali and Kincheloe 1999, 43).

Meanwhile in Europe, these debates have led to an energetic reassessment of the production of knowledge, a lot of it focused at the community level. All communities produce knowledge, invariably linked to notions of place, whether physical or spiritual. This is what Ullrich $\operatorname{Kockel}(2012,62)$ means by 'from-here-ness' - his gloss on the German word Hiesige ('local' or 'locals') - a 
kind of rootedness that arguably has more to do with a community and its traditions than it does to a specific place or location. 'From-here-ness' is an interesting contribution to the debate on the conceptual foundations of decolonial heritage diplomacy but has limitations in the sense that it ignores the importance of what we might call 'from-there-ness' - the knowledge that members of a community, particularly a recently constituted and/or diasporic community, bring with them in the form of traditions, memories (some of them traumatic), rituals and representations of one kind or another (dramatic works, music, fictional narratives and works of art) that help to define that community and preserve its identity and heritage (Grinberg 2019). Therefore, any notion of 'community knowledge' needs to recognize the importance of 'from-there-ness', which is equally important in creating a sense of 'rootedness' among communities, however large or small (Massey 1991).

As a final caveat, it is important to stress that with respect to colonial heritage, we are not dealing with 'a community' in the homogeneous sense of the term but communities in the plural: diverse, multi-layered, plurivocal (Waterton and Smith 2010). This is particularly the case in large urban settings: Lisbon, Rio, Bristol, Warsaw, Paris. In the United Kingdom, a lot of attention is paid to the 'BAME community', which in reality consists of a broad collation of groups-Indian, African, Pakistani, West Indian/ Caribbean - that in different contexts would consider themselves separate communities. The same is broadly true of communities labelled 'Hispanic' or 'Latin American'. Here again, these labels betray Eurocentric notions of community and identity that, in turn, ignore the provenance of specific cultural assets, whether songs, music, art or folklore. Community knowledge is dynamic and malleable and should be given the same consideration as other types of knowledge, not least in diplomatic practice.

\section{Mid-space actors}

Debates about knowledge and the production of knowledge have, in turn, empowered third actors and given them renewed impetus. This is perhaps most evident in the case of museums. In the past, museums tended to align themselves with official (state) versions of the past, or what we might call 'institutional knowledge' (Bennett 2013; Macdonald 2012). But today they are much more likely to be aligned to 'community' and 'indigenous' knowledge (Crooke 2006; Onciul 2015; Watson 2007). This is particularly true in the case of city museums, such as those in Lisbon and Amsterdam, which see it as part of their job to engage with local communities and to represent their concerns, whether cultural, social or environmental (Ariese 2019). Much the same applies to citizens groups and artists, many of which are intent on restoring marginalized voices to view. Citizens groups by definition are rooted in a sense of community knowledge, however loosely defined, just as they are determined to preserve this knowledge and give it some form of expression, whether through music, art or film. 
Symptomatic of this new consensus is the Transperiphery Movement Exhibition in Hungary, a collaboration between curators, academics and artists designed to decolonize Eastern Europe by restoring marginalized histories to view - in this case, the experience of Hungarian migrants in South America, as well as those of Cuban migrant workers in Budapest (Ginelli and Szakács 2020). ${ }^{2}$ Here and elsewhere, curators have emerged as critical voices in debates concerning Europe's colonial heritage. Professor Dan Hicks, Curator of World Archaeology at the Pitt-Rivers Museum in Oxford, has been especially active in leading calls for the restitution of African works of art, not least through the museum network, Action for Restitution to Africa, which works with curators in Europe, as well as Egypt, Ghana and South Africa (Anon 2020). Dan Hicks's broadside, The Brutish Museums: The Benin Bronzes, Colonial Violence and Cultural Restitution (2020) makes a powerful case for the urgent return of such objects, as part of a wider project of addressing the outstanding debt of colonialism - further proof of the growing importance of third actors in forcing us to confront the colonial legacies of Europe's entangled past.

Similarly, artists across Europe, Africa and the Americas have led calls to decolonize museums and art galleries, joining those voices calling for a reckoning with the past-evident not only in the removal of statues and other symbols of colonialism but in the creation of new works that situate slavery at the centre of the black experience (ECHOES 2021). As many of the chapters in this volume demonstrate, artists often draw on a wide range of affective practices in their works, including forms of indigenous and community knowledge (Schütz, this volume). They have also been at the forefront of efforts to go beyond the 'comprehensible' and to create works that initiate 'healing and respect' for others, as witness Meghna Singh's collaborative work Container, which utilizes immersive multimedia to draw uncomfortable comparisons between historical slavery and forms of modern exploitation (Singh, this volume). Artistic practices, as a result, present fertile ground for establishing mid-space 'contact zones' (Pratt 1991). We would go further. Artists should be considered heritage diplomats, reclaiming and repurposing different types of knowledge, while at the same time challenging us to rethink many of the implicit and explicit epistemological hegemonies that work to the detriment of Europe's (and the EU's) engagement with its colonial past and decolonial present (Andersen et al. 2020).

Such interventions have re-energized heritage debates across Europe. They have also succeeded in opening up dialogues, some formal and others informal, that have the potential to impact institutional policy and push it in new directions. In the following sections, we consider two case studies: one historical, the other more contemporary, that speak to this new agenda, emphasizing not simply the broader, interstate, dimension of New Diplomacy Studies but also the importance of mid-space actors and different types of knowledge. 


\section{Arnhem Land expedition: a successful case of restitution}

The first example we consider here is a restitution case involving a major US museum (the Smithsonian Institution in Washington, DC) and a series of Australian diplomatic agents, including Indigenous groups. The focus of this case study is a set of bones taken from - and later returned to - the Aboriginal area of Arnhem Land in Australia's Northern Territory in the 1940s. In 1948, following years of exchanges involving scientists and official government representatives, a large-scale joint US-Australian expedition was planned to explore Arnhem Land, an area that was presented as a place to explore pristine, primitive cultures. The initiative was, as researchers note, a political act, embroiled in Cold War politics, as Australia was keen to build better relations with the United States and to distance itself more from the United Kingdom (Beazley 2011). The composition of the scientific expedition team also reflected these politics, being made up of a mix of Australian and Smithsonian researchers. It was led by the Australian ethnologist Charles P. Mountford, assisted by the archaeologist Frank M. Setzler from the Smithsonian Institution (Thomas 2011, 2014). The scientific team included an ornithologist, mammologist, ichthyologist, botanist and other scientists, each with a particular interest in an aspect of the life and natural surroundings of the Arnhem Land.

This expedition followed the old-fashioned 'expeditionary' style of gathering knowledge, with little or no input from the researched Indigenous populations (Thomas 2011). Tens of thousands of artefacts were collected, from tools to crafts, to flora specimens. Significantly, the bones that became the crux of this case study were not officially part of the expedition's scope; indeed, their removal from the territory was hidden for a few years after the end of the expedition. Even their removal was arguably fraudulent. Frank Setzler, having seen the bones in a cave, waited for the guides helping him to fall asleep after lunch before seizing them. Based on the terms negotiated before the start of the expedition, collected items were divided between the United States and Australia. The hidden bones were subsequently sent on to the Smithsonian with the other artefacts collected during the expedition.

In line with our discussions in the first part of this chapter on actors involved in diplomatic engagements, a closer examination of both the expedition and the recent repatriation campaign events shows a complex network of agents, both official and unofficial. The original 1940s lobby and negotiation work, for instance, can be attributed to key Australian people such as influential politician Arthur Calwell, Minister of Information at the time, Alexander Wetmore, Secretary of the Smithsonian Institution, and Gilbert Grosvenor, President of the Australian National Geographic Society (Beazley 2011; May 2011). These interactions, mediated by formal and informal channels, led to the shared Arnhem Land expedition.

The events that led to the case for restitution show an equally complex web of agents involved in the process. The Smithsonian was initially reluctant to 
respond to any claims for restitution. Martin Thomas $(2011,2014)$ notes that the restitution of the bones was the result of a long process that began as early as the late 1990s, with various governmental and non-governmental agents involved in the lobbying activities. Aboriginal elders, anthropologists and Indigenous groups demanded their return and, eventually, even the Australian government became involved. In 2005, as a result of these initiatives, the Chair of the Aboriginal and Torres Strait Islander Commission, Lionel Quartermaine, formally wrote to the Smithsonian to request the return of the bones.

The defining event that, according to researchers (Neale 2011), swayed the views of the Smithsonian took place in 2009. That year, a symposium was held at the National Museum of Australia in Canberra that discussed, among other topics, the issue of the bones. The symposium, which had Indigenous people in attendance from across the area covered by the expedition, included a passionate plea from the Aboriginal elder Thomas Amagula for full restitution of the objects. In a telling reference, Amagula alluded to US efforts to repatriate the remains of US soldiers who had lost their lives overseas. Reflecting on this intervention, the director of the symposium, Margo Neale, later wrote that:

I believe this was a case of the power of soft diplomacy over political pressure. Representatives from the Smithsonian in the audience were able to experience the human dimension of the impact of missing ancestral remains, as community members spoke of their distress at the loss, and the shame they felt at not being able to save their 'old people'.

(Neale 2011, 435)

Although we would take the notion of soft diplomacy discussed by Neale with a grain of salt, we can see the importance of third actors clearly here, empowered to voice their opinions and build necessary alliances to ultimately influence interstate and interinstitutional relations to the benefit of their cause.

Diplomacy, as Constantinou (2013) notes, entails a sensitivity towards difference and a genuine openness towards diverse knowledge paradigms. Catalogued as human remains, based on a Western taxonomy of artefacts, the Smithsonian researchers placed the indigenous bones in storage. Thomas (2014) reflects on the transformation of subjects into objects, how the bones were treated in a similar way to the other artefacts collected from the expedition, whereas, according to indigenous ways of thinking, they had not lost their subjectivity, just because the people involved were dead (Thomas 2015b). This is why he contends that a more accurate description of Setzler's action would be kidnapping, rather than theft. Moreover, what we see at play here is the reproduction of colonial power relations, where community knowledge is relegated to the margins and institutional knowledge prevails. 
A moment when this mismatch of knowledge paradigms became all too evident was in the response of the Smithsonian's representatives to the restitution claims. Ignoring these calls for decades, the Smithsonian finally returned a part of the bones in 2009 (Thomas 2015a). A year later, the remaining bones were prepared for return and three local representatives from Groote Eylandt, Gunbalanya and Milingimbi (Victor Gumurdul, Thomas Amagula and Joe Gumbula) travelled to Washington, DC, to collect them, where they performed a smoking and singing ceremony to appease the anger of the spirits that had been wrenched from their country. The ancestral remains were subsequently brought back to Gunbalanya where another (and more broadly representative) ceremony was performed a year later.

To the Arnhem Land's Indigenous people, these bones were never mere objects. Within their ontology, a clear connection existed between the bones and the spirits of their ancestors. The moving documentary Etched in Bone (Thomas and Bijon 2018) clearly presents the distraught community trying to appease the anger of these lost souls. The burial ceremony was presided over by one of the last remaining elders, Jacob Nayinggul, who spoke various Indigenous languages that the deceased might have spoken during their lifetimes (Thomas 2015b). Thomas reflects powerfully on the importance of this moment of return: 'Living Aboriginal people find their navigational points on their country by knowing the dead are in certain places' (Murdoch 2011). Thus, within the community, the presence or absence of these ancestral remains mattered more deeply than in the institutional logic where they were classed as artefacts and hidden away in a cupboard.

The Arnhem Land restitution campaign, long-winded as it was and involving different types of actors, led to positive changes in Australia's policy field. The case study thus underscores some of Constantinou's $(2013,158)$ observations on the proliferation of a 'diplomacy from below and from noncentralized places combined with transnational issue-specific actorship, often with rich and rival knowledge resources'. In 2011, the Australian Government created a dedicated repatriation policy, as well as an all-Indigenous International Repatriation Advisory Committee, that aims to provide opportunities for active engagement in such cases, including the agency to decide when and how the repatriation should take place.

The same cannot be said of the Smithsonian Institution. Repatriation claims continue to be considered on a national basis mostly, based on the National Museum of the American Indian Act (1989, amended 1996). Thomas (2015b) notes that there is no homogenous approach to repatriation claims across the Smithsonian Institution's different museums and that his attempts to officially discuss the Armhem Land episode with staff members of the National Museum of Natural History were turned down. Moreover, informal discussions suggested the claim was treated as "the return of a "loan" rather than a "repatriation"' (Thomas 2015b, 155).

The situation does not seem to have changed much since 2015. The museum's current policy only refers to Native Americans and Native 
Hawaiian people (NMNH 2012), and mentions that international requests are 'contingent upon international agreements, unless the materials in question are found to have been acquired illegally or under circumstances which render the NMNH's claim of title invalid'. The National Museum of the American Indian, on the other hand, seems to be more open. While its repatriation policy (NMAI 2020) focuses on the same groups mainly, it also mentions that requests from international indigenous communities will be considered on 'a case-by-case basis' (NMNH 2012, 8). This case study therefore shows how different types of knowledge can coexist, or, rather, how they can generate tensions in contentious matters such as repatriation claims. More importantly, however, it also shows how different types of agents, official and unofficial can work together to bring about beneficial results at both the national and international levels.

\section{A museum for Danish colonial history}

During the spring and summer of 2020, Danish politicians and members of parliament across the political spectrum expressed their support for the idea that Denmark should have a museum dedicated to the country's colonial history (B. Nielsen 2020a). This idea originated among non-state groups, including the association Kolonihistorisk Center, an NGO that since 2015 has worked to create awareness about the colonial history and heritage of Denmark (Kolonihistorisk Center n.d.). The plan was to locate the museum in the former West India Warehouse (Vestindisk Pakhus) built in the port entry of Copenhagen in 1780-1781 to store goods from Denmark's colonial possessions in the West Indies. While the outcome remains undecided, the case of the museum highlights two characteristics that we have identified as key markers for decolonial heritage diplomacy: the initializing influence of non-state agents whose activities spurs or forces politicians to act; and secondly, the mobilization of knowledges and pluriverse epistemologies to create awareness and promote institutional change.

As in other Western European countries, colonial history and heritage have been the subject of increased attention in Denmark during recent years, and the idea to establish a museum for colonial history must be seen in this context. Specifically, the centenary in 2017 of the transfer of the Danish West Indies to the United States (since then known as the US Virgin Islands) constituted a key moment with elaborate commemorative activities across Denmark, which included also numerous museum exhibitions. Based on an extensive study of nineteen of these centenary exhibitions and interviews with 26 curators, leading expert on Danish colonial heritage Astrid Nonbo Andersen concludes that '[c]ompared to the previous neglect of this history [of colonialism] in Danish museums the 2017 special exhibitions in this regard represented a major leap forward' (Andersen 2019, 77).

Curatorial practices and ideals differed widely across this exhibition landscape but were generally informed by what Lorena Sancho Querol refers 
to as cultural and museological mediation, aimed at 'the promotion of greater citizen participation and expression, giving shape to processes of building connections between the cultural and social realms', which in museum contexts covers a broad spectrum of practices, ranging from audience development activities to participatory museology (Querol 2020). Two exhibitions from the centenary year exemplify this. The first, Blind Spots: Images of the Danish West Indies Colony, in the Danish Royal Library in Copenhagen, was curated by art historians and focused on the history of slavery, inviting audiences to engage critically with present-day manifestations of racial stereotypes in a range of media contexts (Andersen 2019, 67-8). Meanwhile, at the Danish National Museum, the exhibition Voices from the Colonies placed the history of the Danish West Indies within a broader context of Danish colonialism and centred the narrative around 37 individuals and their stories (V. Nielsen 2020b).

There was extensive involvement of artists in both of these exhibitions. In Voices from the Colonies, clay figurines made by Beninese artists Marcelline Hounhouenou and Agathe Yaovi were used in displays that addressed Denmark's role in the transatlantic slave trade. This part of the exhibition built on existing collaborations with curators in Benin and, as one of the curators in Copenhagen, Louise Sebro, explains, the shared ambition of the curators was to find a way 'to show the scale of enslavement and awfulness of the structure [of slavery] while trying to find ways of insisting on the humanity and individuality of those who were enslaved' (Klint 2018). The work of artists went beyond exhibition spaces, however. The Danish-Caribbean artist Jeannette Ehlers and St Croix artist La Vaughn Belle were both involved in the Blind Spots exhibition in the Royal Library and later collaborated to create a sculpture modelled on Queen Mary, one of the main leaders of a labour revolt in St Croix in 1878, known as the Fireburn. Entitled I Am Queen Mary, the 7-meter tall monumental public sculpture is located in front of the West India Warehouse, the building now under consideration to house the museum for colonial history (Knudsen 2018; Yoon Pedersen 2018) (Figure 15.1).

The former warehouse is owned by the National Gallery of Denmark and is used to store and display the Royal Cast Collection, a collection of more than 2,000 plaster casts of seminal sculptures from Greek antiquity to the Renaissance. The Royal Cast Collection was established during the eighteenth and nineteenth centuries and is, in part, testament to a Winckelmanian-like elevation of 'whiteness' as the foundational ideal of beauty in European art - an ideal that became entrenched during this period. The entangled black and white histories within the former colonial warehouse were used by Ehlers in 2014 in her video installation Whip It Good in a forceful critique of colonial imagery, aesthetic ideals and contemporary racism. As art historian Mathias Danbolt notes, students and artists traditionally have brought their white canvases to the Cast Collection to copy the canonical examples in the history of European art, whereas the artist-protagonist in Ehlers' video performance 


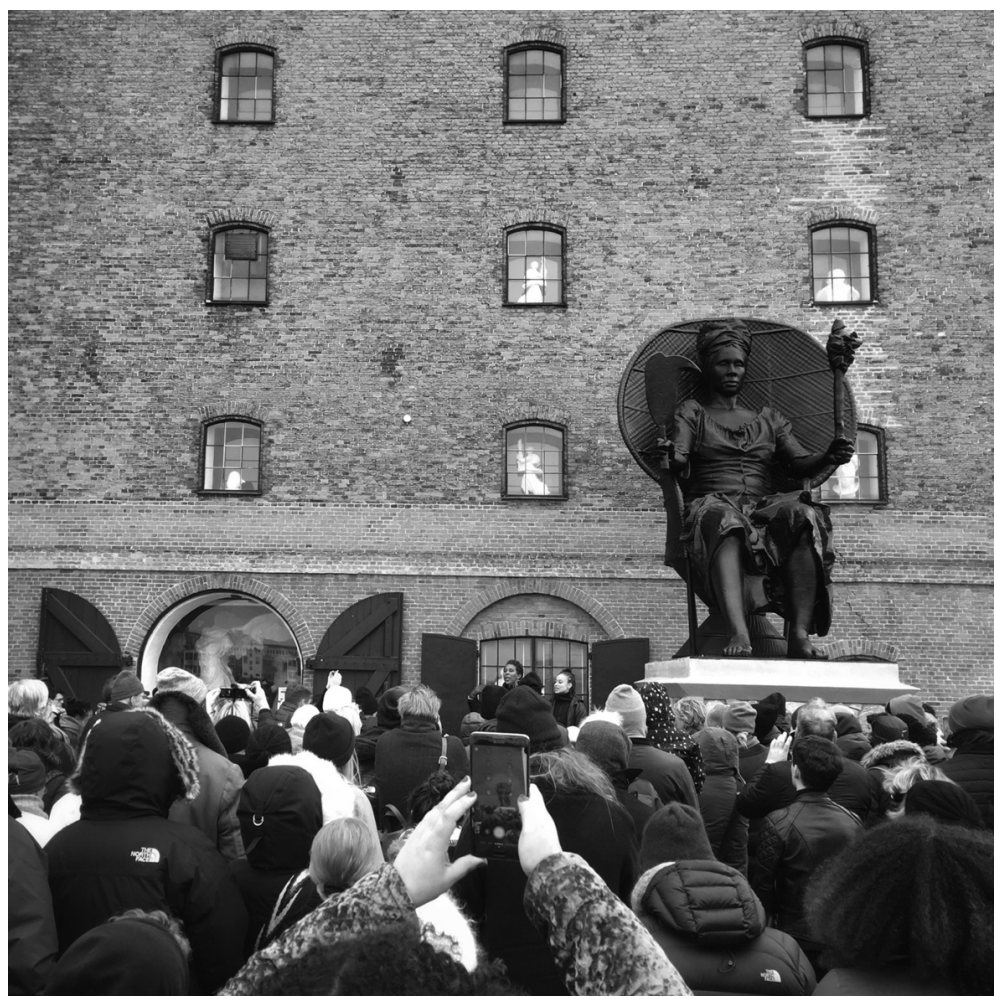

Figure I5.I Inauguration of IAm Queen Mary by the formerWest India Warehouse, Copenhagen. Courtesy of La Vaughn Belle and Jeannette Ehlers.

Photo by Sarah Giersing, 2018.

is not here to learn history by copying it, she is here to give it a beating. Appearing as a reconfigured black Goddess of vengeance, she strikes back at the persistent myth of Greece as the cradle of Western art and Modernity - a myth that has fueled the co-constituted discourse of modernity/coloniality.

(Danbolt 2016, 281)

The interventions in and around the former warehouse forcefully re-established the connections between the physical building, colonial history and contemporary coloniality. As art historian Ida Nørgaard notes, what is most significant about I Am Queen Mary is her location:

Placed in front of the West Indian Warehouse, that for 250 years was used to store Caribbean sugar and rum brought in from the colonies and today houses the Royal Cast Collection which set the stage for Ehlers 
video work of Whip it Good, the queen stands out as a counter-narrative to the dominance of Eurocentrism represented in this place.

(Nørgaard 2020)

As Knudsen emphasizes, the statue creatively reinstates the entangled histories of Denmark and the US Virgin Islands. I Am Queen Mary, she argues, is a key example of an intervention in the modality of 're-emergence', that is, 'a lost opportunity from the past that returns to offer itself for creating alternative futures' (Knudsen 2018). The entangled histories almost literally become concrete in the plinth of the statue, which has been made of coral stones originally cut from the ocean around the US Virgin Islands by enslaved Africans and used for buildings on the islands during the colonial era. Moreover, using modern scanning technology, the face and body of the statue is created as a hybrid between Mary and the two contemporary artists Belle and Ehlers. Pointing out the wider significance of the artists' intervention, Knudsen concludes that I Am Queen Mary serves to destabilize

the internal homogeneity of an expanded Danish nationhood, of Copenhagen joining a community of former colonizers (finally) commemorating colonialism. It introduces an intercultural communal multi-vocal artistic work as a politically appropriate answer to colonial heritage issues ... Here, multiple sources are at play, they merge, emerge and re-emerge, at one and the same time, representing all of them and none of them entirely, with the past-future axis blown apart, and with a hopeful modesty, depicting the not yet of a more inclusive future.

(Knudsen 2018)

In this case from Copenhagen, we see how alliances between curators, academics, artists and institutions have collaborated to produce significant public awareness of a previously marginalized side of Danish history. The creative use of the entangled histories indicates how curatorial and artistic practice can make concrete the abstract ideals of connecting 'from-thereness' and 'from-here-ness' to help create a sense of rootedness for different communities living within the same space.

In particular, the work of these groups has re-established the connection between the West India Warehouse, colonial history and the need to confront racism and marginalization in the present. When politicians, members of parliament and state bureaucracies are now considering a formal institutionalization of Danish colonial history in the former warehouse, they do so in response to the activities that non-state agents have carried out to create awareness of coloniality and, just as important, to connect it to the histories within this space. It is by no means certain, however, that this (decolonial) interpretation of an entangled past and present will prevail. In Denmark, colonial heritage remains a contested space and groups with more 
conservative - if not outright celebratory-interpretations of Denmark's colonial past have also seized upon the opportunities created when third agents initiate discussions about colonial heritage in order to try and advance their own agendas. To us, however, this ongoing situation only underscores the continued need for mid-space diplomatic efforts that connect plural locations and diverse viewpoints.

\section{Conclusion}

In their different ways, these case studies demonstrate how grassroots movements and independent cultural actors can successfully initiate meaningful intercultural dialogue and, in the process, build more equitable systems of collaboration and representation. They also highlight the importance of mediation, facilitated by mid-space actors attuned to the different values that states and groups attach to the same cultural artefacts. This brings us back to the question of 'active listening'. Where a former colonial relation is known to exist, this history needs to be brought into the discussion, so that the effects of its legacy in the present can be openly discussed and interrogated, not with a particular agenda in mind but with the intention of mitigating unequal power relations. In the same way, institutions and policymakers at all levels need to carefully tailor their activities and processes so as to respond to and incorporate hitherto marginalized voices (ECHOES 2021).

Decolonisation is not an event but an ongoing, continuous process. If we are to face up to the enduring legacies of past wrongdoings and create a future that is both fair and equitable, then we need to move away from official narratives and Eurocentric notions of 'heritage'. A decolonial approach to ICR stresses the importance of dialogue and active listening, appreciates different perspectives and recognizes the importance and value of different types of knowledge: 'indigenous', 'local' or 'community'. Whether labelled as heritage diplomacy or ICR, international collaboration projects and initiatives that address past colonial entanglements need to be based on a foundation of trust and mitigate against unequal power relations between partners. In other words, we advocate a holistic approach that recognizes the different ways knowledge and heritage are produced and consumed, as the foundation for decolonial heritage practice, both inside and outside Europe.

\section{Notes}

1 This work forms part of the ECHOES project which has received funding from the European Union's Horizon 2020 research and innovation programme under grant agreement No. 770248.

2 The Transperiphery Movement is an independent interdisciplinary exhibition project curated by Eszter Szakács and Zoltán Ginelli. It was originally planned to open during the Biennale Budapest 2020 edition; however, the event was cancelled due to the coronavirus crisis and postponed for 2021 (Ginelli and Szakács 
2020). The exhibition brings together hidden histories of colonial relations in Eastern Europe with the Global South, relations that are often disregarded in postcolonial studies. The project combines academic research with modern art created by an international group of artists from across Eastern Europe. The exhibition also has a strong educational focus, a series of engagement activities with pupils are planned to help them understand the complexities of Hungary's recent past and counteract nationalistic approaches to history teaching.

\section{References}

Afrikan Liberation 1988. "Conversation with Chinua Achebe." Accessed 1 September 2020. https://www.youtube.com/watch?v=_8gjYpKwV7I.

Andersen, Astrid N. 2019. "Curating Enslavement and the Colonial History of Denmark." In Museums and Sites of Persuasion, edited by J. Apsel and A. Sodaro, 57-61. London: Routledge.

Andersen, Casper, Cristina Clopot, and Jan Ifversen. 2020. "Heritage and Interculturality in EU Science Diplomacy." Humanities and Social Sciences Communication 7 (1): 1-8.

Anon. 2020. "Museums and Restitution: Legacies of Violence." The Economist, 8 August, 70-72.

Ariese, Csilla E. 2019. Decolonizing the Amsterdam Museum: A Work-in-Progress to Becoming a More Inclusive City Museum. Amsterdam Museum Report 2. Accessed 2 September 2020. http://projectechoes.eu/wp-content/uploads/Ariese-AmsterdamMuseum-Report-2_compressed-1.pdf.

Beazley, Kim 2011. "Nation Building or Cold War: Political Settings for the Arnhem Land Expedition." In Exploring the Legacy of the 1948 Arnhem Land Expedition, edited by M. Thomas and M. Neale, 55-72. Canberra: Australia National University Press.

Bennett, Tony. 2013. The Birth of the Museum: History, Theory, Politics. London: Routledge.

Canagarajah, Suresh. 2002. "Reconstructing Local Knowledge.” Journal of Language, Identity, and Education 1 (4): 243-59.

Cornago, Noé. 2013. Plural Diplomacies: Normative Predicaments and Functional Imperatives. Leiden: Brill.

Constantinou, Costas M. 2000. "Diplomacy, Grotesque Realism, and Ottoman Historiography.” Postcolonial Studies: Culture, Politics, Economy 3 (2): 213-26.

Constantinou, Costas M. 2013. "Between Statecraft and Humanism: Diplomacy and Its Forms of Knowledge." International Studies Review 15 (2): 141-62.

Cooper, Andrew F., and Brian Hocking, 2000. "Governments, Non-governmental Organisations and the Re-calibration of Diplomacy. Global Society 14 (3): 361-76.

Crooke, Elizabeth. 2006. "Museums and Community." In A Companion to Museum Studies, edited by Sharon Macdonald, 170-85. Malden: Blackwell Publishing.

Danbolt, Mathias. 2016. "Striking Reverberations: Beating Back the Unfinished History of the Colonial Aesthetic with Jeannette Ehlers's Whip it Good.". In Otherwise: Imagining Queer Feminist Art Histories, edited by Amelia Jones and Erin Silver, 276-93. Manchester: Manchester University Press.

Di Martino, Luigi. 2020. "The Spectrum of Listening." In Routledge Handbook of Public Diplomacy, edited by Nancy Snow and Nicholas J. Cull, 21-9. London: Routledge. 
Eban, Abba. 1999. Diplomacy for the Next Century. New Haven: Yale University Press.

ECHOES. 2021. "A Renewed Impetus for Reflection on our Colonial Legacies in 2020.” http://projectechoes.eu/wp-content/uploads/ECHOES_heritage-diplomacypolicy-brief_3_final.pdf.

EUNIC. 2020. "For the Future: Make Cultural Relations Count in a Post-Crisis Global Society.” EUNIC, 8 June. https://eunicglobal.eu/news/eunic-statement.

Geertz, Clifford. 1983. Local Knowledge: Further Essays in Interpretive Anthropology. New York: Basic Books.

Ginelli, Zoltán, and Eszter Szakács. 2020. Personal communication, 25 June.

Grinberg, Keila. 2019. "O mundo não é dos espertos: história pública, passados sensíveis, injustiças históricas: Public History, Sensitive Pasts and Historical Injustices.” História da Historiografia 12 (31): 145-76.

Hicks, Dan. 2020. The Brutish Museums: The Benin Bronzes, Colonial Violence and Cultural Restitution. London: Pluto Books.

Klint, Sigurd. 2018. "Når man fortæller om slaveri: En samtale med Louise Sebro." Baggrund. Accessed 29 October 2020. https://baggrund.com/2019/10/22/ nar-man-fortaeller-om-slaveri/?utm_source=rss\&utm_medium=rss\&utm_ campaign=nar-man-fortaeller-om-slaveri.

Knudsen, Britta Timm. 2018."Re-emergence.” ECHOES: European Colonial Heritage Modalities in Entangled Cities. Accessed 8 March 2021. https://keywordsechoes. com/re-emergence.

Kockel, Ullrich. 2012. "Being from and Coming to: Outline of an Ethno-Ecological Framework." In Radical Human Ecology, edited by Lewis Williams, Rose Roberts, and Alastair McIntosh, 57-69. Farnham: Ashgate.

Kolonihistorisk Center. n.d.. Accessed 29 October 2020. http://kolonihistoriskcenter.dk.

Macdonald, Sharon J. 2012. "Museums, National, Postnational and Transcultural Identities." In Museum Studies: An Anthology of Contexts, edited by B. M. Carbonell, 273-87. Malden: Blackwell.

Massey, Doreen. 1991 “A Global Sense of Place.” Marxism Today, 24-9. http://banmarchive.org.uk/collections/mt/pdf/91_06_24.pdf.

May, Sally K. 2011. "Piecing the History Together: An Overview of the 1948 Arnhem Land Expedition." In Exploring the Legacy of the 1948 Arnhem Land Expedition, edited by Martin Thomas and Margo Neale, 171-90. Canberra: Australia National University Press.

Murdoch, Lindsay. 2011. "Stolen Spirits Brought Home to Be at Rest." The Sydney Morning Herald, 20 July. https://www.smh.com.au/national/stolen-spirits-broughthome-to-be-at-rest-20110719-1hnbv.html.

Murray, Stuart, Paul Sharp, Geoffrey Wiseman, David Criekemans, and Jan Melissen. 2011. "The Present and Future of Diplomacy and Diplomatic Studies." International Studies Review 13 (4): 709-28.

National Museum of Natural History (NMNH). 2012. "Guidelines and Procedures for Repatriation.” Accessed 13 September 2020. https://naturalhistory.si.edu/sites/ default/files/media/file/repatriation-guidelines-and-procedures-2012.pdf.

National Museum of the American Indian (NMAI). 2020. "Repatriation Policy." Accessed 12 September 2020. https://americanindian.si.edu/sites/1/files/pdf/ repatriation/NMAI-Repatriation-Policy-2020-final.pdf.

Neale, Margo 2011. "Epilogue: Sifting the Silence." In Exploring the Legacy of the 1948 Arnhem Land Expedition, edited by Martin Thomas and Margo Neale, 42336. Canberra: Australia National University Press. 
Nielsen, Bodil S. 2020a. "Editorial: Giv Danmark et kolonihistorisk museum." Information, 18 June. https://www.information.dk/kultur/leder/2020/06/ giv-danmark-kolonihistorisk-museum-goer-alvor-opgoeret-slavehandlen.

Nielsen, Vibe. 2020b. "Hvis Stemmer? Da kolonitiden for alvor kom på museum." Baggrund. Accessed 28 October 2020. https://baggrund.com/2020/01/29/ hvis-stemmer-da-kolonitiden-for-alvor-kom-paa-museum/.

Nørgaard, Ida. 2020. "The Subversive Potential of Visual Violence in Contemporary Art." Idolart. Accessed 28 October 2020. https://www.idoart.dk/blog/ the-subversive-potential-of-visual-violence-in-contemporary-art.

Oguamanam, Chidi. 2008. "Local Knowledge as Trapped Knowledge: Intellectual Property, Culture, Power and Politics." The Journal of World Intellectual Property 11 (1): 29-57.

Onciul, Bryony. 2015. Museums, Heritage and Indigenous Voice: Decolonizing Engagement. London: Routledge.

Opondo, Sam O. 2010. "Decolonizing Diplomacy: Reflections on African Estrangement and Exclusion." In Sustainable Diplomacies, edited by Costas Constantinou and James Der Derian, 109-27. London: Palgrave Macmillan.

Pratt, Mary. L. 1991. "Arts of the Contact Zone.” Profession 12 (1): 33-40.

Querol, Lorena Sancho. 2020. "Reflecting on Re-emotions of Heritage of Colonial Origin with Rosário Severo at the National Museum of Ethnology." Alice Comments: Echoes Life Stories. Accessed 28 October 2020. https://alicenews.ces. uc.pt/index.php?lang=1\&id=31048.

Quiroz, Consuelo. 2002. "Local Knowledge Systems and Vocational Education in Developing Countries." In What Is Indigenous Knowledge: Voices from the Academy, edited by Ladislaus M. Semali and Joe L. Kincheloe, 305-16. London: Taylor and Francis.

Semali, Ladislaus M., and Joe L. Kincheloe. 1999. "Introduction: What Is Indigenous Knowledge and Why Should We Study It." In What Is Indigenous Knowledge: Voices from the Academy, edited by Ladislaus M. Semali and Joe L. Kincheloe, 357. London: Taylor and Francis.

Thomas, Martin. 2011. "Expedition as Time Capsule: Introducing the AmericanAustralian Scientific Expedition to Arnhem Land." In Exploring the Legacy of the 1948 Arnhem Land Expedition, edited by Martin Thomas and Margo Neale, 1-30. Canberra: Australia National University Press.

Thomas, Martin. 2014. "Turning Subjects into Objects and Objects into Subjects: Collecting Human Remains on the 1948 Arnhem Land Expedition." In Circulating Cultures: Indigenous Music, Dance and Media in Australia, edited by Amanda Harris, 129-66. Canberra: Australia National University Press.

Thomas, Martin. 2015a. "Because It's Your Country: Death and Its Meanings in West Arnhem Land.” Life Writing 12 (2): 203-23.

Thomas, Martin. 2015b. "Bones as a Bridge between Worlds: Responding with Ceremony to the Repatriation of Aboriginal Human Remains from the United." In Conciliation on Colonial Frontiers: Conflict, Performance, and Commemoration in Australia and the Pacific Rim, edited by Kate Darian-Smith and Penelope Edmonds, 150-67. London: Routledge.

Thomas, Martin, and Béatrice Bijon. 2018. Etched in Bone. Australia: Red Lily Productions. $73 \mathrm{~min}$.

United Nations (UN). n.d. "Who Are Indigenous Peoples?" Accessed 1 September 2020. https://www.un.org/esa/socdev/unpfii/documents/5session_factsheet1.pdf. 
United Nations (UN). 2007. "United Nations Declaration on the Rights of Indigenous Peoples." Accessed 1 September 2020. https://www.un.org/development/desa/ indigenouspeoples/wp-content/uploads/sites/19/2018/11/UNDRIP_E_web.pdf.

UNESCO. n.d. "Local and Indigenous Knowledge Systems." Accessed 1 September 2020. http://www.unesco.org/new/en/natural-sciences/priority-areas/links/relatedinformation/what-is-local-and-indigenous-knowledge.

Vanhulst, Julien, and Adrien E. Beling. 2014. "Buen Vivir: Emergent Discourse within or beyond Sustainable Development?" Ecological Economics 101: 54-63.

Walsh, Catherine E. 2018. "Decoloniality in/as Praxis." In On Decoloniality: Concepts, Analytics, Praxis, edited by Walter D. Mignolo and Catherine E. Walsh, 15-104. Durham: Duke University Press.

Waterton, Emma and Laurajane Smith, 2010. "The Recognition and Misrecognition of Community Heritage.” International Journal of Heritage Studies 16 (1/2): 4-15.

Watson, Sheila E. R. ed. 2007. Museums and Their Communities. London: Routledge.

Winter, Tim. 2015. "Heritage Diplomacy." International Journal of Heritage Studies 21 (10): 997-1015.

Yoon Pedersen, Christina. 2018. "Syv meter høj statue skal minde os om vores fortid som slaveejere." Berlingske tidende, 10 April. https://www.berlingske.dk/kultur/ syv-meter-hoej-statue-skal-minde-os-om-vores-fortid-som-slaveejere.

Zondi, Siphamandla. 2016. "A Decolonial Turn in Diplomatic Theory: Unmasking Epistemic Injustice.” Journal for Contemporary History 41 (1): 18-37. 